\title{
Autonomous underwater videography and tracking of basking sharks
}

\author{
L. A. Hawkes ${ }^{1 *}$ (D, O. Exeter ${ }^{2}$, S. M. Henderson³ ${ }^{3}$ C. Kerry², A. Kukulya ${ }^{4}$, J. Rudd', S. Whelann ${ }^{4}$, N. Yoder ${ }^{4}$ \\ and M. J. Witt' ${ }^{1}$
}

\begin{abstract}
Background: Biologging studies have revealed a wealth of information about the spatio-temporal movements of a wide range of vertebrates large enough to carry electronic tracking tags. Advances in autonomous underwater vehicles (AUVs or UAVs) and unmanned aerial vehicles (commonly known as drones), which can carry far larger payloads of sensor technologies, have revealed insights into the environment through which animals travel. Some AUVs have been used to film target animals, but are generally limited to periods as long as a drone operator can actively follow an animal. In the present study, we use an AUV, the REMUS-100 SharkCam, paired with a custom transponder tag attached to the shark, to autonomously follow three basking sharks for a cumulative total of $10.9 \mathrm{~h}$ to collect video and environmental data on their sub-surface behaviour. The basking shark is the second largest fish in the world and is endangered globally, but despite being subject to various biologging studies, little is known of this species breeding ecology and their mating grounds remain unknown.
\end{abstract}

Results: We detail the first successful autonomous tracking of basking sharks, comprising three missions that filmed basking sharks in mid-water and close to benthic habitats. Sharks spent very little time feeding, and travelled relatively close to sandy, rocky and algae-covered benthos. One basking shark was observed defecating. Conspecifics were not observed in the three missions, nor were courtship or breeding behaviours. AUV offset distances for videography were determined iteratively through tracking. These offsets varied depending on the trade-off of between water clarity and proximity of the AUV for obtaining useful video data and directly influencing shark behaviour.

Conclusions: The present study is the first successful use of an AUV to gain insight into the sub-surface behaviour of basking sharks.

Keywords: AUV, Biologging, Basking shark, Videography, SharkCam

\section{Background}

Revolutions in digital technology have yielded an ever-increasing range of electronic tools to track the three-dimensional movements of terrestrial and aquatic animals over space and time $[1,2]$, as well as their internal state and physiology [3-6]. In the marine realm, there is now a good understanding of the

*Correspondence: I.hawkes@exeter.ac.uk

${ }^{1}$ Environmental Biology Group, Hatherly Laboratories, University of Exeter, Prince of Wales Road, Exeter EX4 4PS, UK

Full list of author information is available at the end of the article spatio-temporal distribution of a range of large marine vertebrate groups, such as marine mammals [7], sea turtles [8, 9], sharks [10] and seabirds (Seabird Tracking Database, BirdLife International, http://www.seabirdtra cking.org/). The first animal ever to be tracked by the now ubiquitous Argos satellite system was a basking shark in 1982 [11], using a towed system that recorded up to 12 locations a day for 17 days, giving insights into their use of Scottish waters. Subsequent work on basking sharks has revealed that western Scottish waters are an important international hotspot for basking shark occurrence [12-15]. In addition, conspicuous 
nose-to-tail following behaviour of basking sharks has been noted in Scottish waters [16, 17], which is indicative of courtship in many shark species (reviewed in [18]). Despite this, basking shark breeding has never been reported in the peer-reviewed scientific literature, although one tentative account exists in a non-technical magazine [19]. Thus, while spatio-temporal tracking can reveal considerable insights into animal ecology, the method often does not reveal the context or motivations for animal movement, and past tracking has not been able to resolve whether basking sharks breed in Scottish waters.

Developments in autonomous underwater vehicles (AUVs) and remote sensing have now opened up the possibility of using robotic camera and sensing technologies to film both the environment [20] and animals themselves [21]. These AUVs can carry larger payloads, and thus collect more sensor data, and because they can carry a larger payload of batteries, can often last longer than animal-borne cameras. AUVs have been used, for example, to film leatherback sea turtles, bull and great white sharks [22-24]. In the present study, basking sharks (Cetorhinus maximus) were tagged with a custom acoustic tracking beacon, also recording temperature and pressure ('retag' from hereon), and filmed using a REMUS-100 SharkCam Autonomous Underwater Vehicle (AUV from hereon) that could locate and autonomously follow the retag, in the waters of the Inner Hebrides, Scotland (Fig. 1a). The AUV was fitted with five GoPro video cameras mounted to record forwards, upwards, downwards, port and starboard (Fig. 1b). To contextualize the environment in proximity to the shark the AUV was fitted with a conductivity temperature depth sensor (YSI.com), an EcoPuck (SeaBird Scientific; gathering information on chlorophyll-a concentration, fluorescent dissolved organic matter and turbidity), and an up/down acoustic Doppler current profiler $(1200 \mathrm{kHz}$; Teledyne RD Instruments; gathering information on altimetry, water current and speed over ground; see [21-23] for technical details of the AUV configuration). The overall purpose of the project was to attempt to film courtship and mating by basking sharks in Scottish waters, as well as to gain a greater insight into basking shark behaviour sub-surface (at depths where they can cannot be directly observed).

\section{Results}

Between 11th and 16th July 2019, three AUV missions were conducted on two female and one male basking shark gathering a range of insights into surface and subsurface behaviour of these animals (Table 1; Fig. 2). Missions comprised 10.9 cumulative hours of video data.

\section{Mission 1}

The shark was tagged approximately $3 \mathrm{~km}$ north of Gunna Sound, between Coll and Tiree, and spent the entire tracking period $(250 \mathrm{~min})$ travelling south through Gunna Sound (Fig. 3b). During the mission the support vessel travelled $14.1 \mathrm{~km}$ tracking both the AUV and the retag. The shark swam close to the seabed ( $2.9 \mathrm{~m}$ above, median, IQR: $1.2 \mathrm{~m}$ ), and the video data revealed that this was primarily sandy, and sand-kelp benthic habitats. This shark made no ascent towards the surface during the tracking period (Fig. 4a). The shark was not recorded feeding (i.e. with its mouth open) at any time during the mission. No courting or mating behaviours were observed. Horizontal visibility at the site was poor (as estimated from the video, generally $<10 \mathrm{~m}$; Table 1), restricting the field of view of the cameras in comparison to the later missions. The video data were able to confirm the sex of the shark (female) from the upward facing camera as the shark swam over the AUV, as well as to document colouration, markings and fin shape for possible future photo identification. Acoustic tracking of the retag and of the AUV, revealed that the shark made 66 circling movements, while the AUV made 104 circling movements following the shark.

Shark tail-beat frequency (TBF) could be estimated from gathered video data and was $0.27 \pm 0.07 \mathrm{~Hz}$ (mean $\pm 1 \mathrm{SD}$, range 0.16 to $0.44 \mathrm{~Hz}, n=15$ ). Post-mission analysis of the video data revealed that the nose cone of the AUV made contact with the shark on two occasions, once against the caudal peduncle recorded by the bow camera, and once on the tail recorded by the portfacing camera. Contact events generally occurred when the residual speed in the AUV, following deceleration on approach to the retag, was influenced by local currents or unpredictable changes in shark speed or direction, such that the AUV was unable to stop before contact with the shark. Contact events resulted in the shark accelerating away from the AUV (mean TBF $=0.45 \mathrm{~Hz}$ ) and out of visible range of the video data. The biotic environment through which the shark travelled was also recorded; for example, a pod of six bottlenose dolphins (Tursiops truncatus) remained around the AUV and shark for just over one minute. After reviewing the speed and movement of the shark in Mission 1, tracking offsets were increased to minimize opportunity for contact between the shark and the AUV.

\section{Mission 2}

The shark was tagged approximately $12 \mathrm{~km}$ south of Tiree (Fig. 3c). The AUV was additionally fitted with a rearward facing camera for this mission. The effect of this camera on the hydrodynamics and buoyancy 


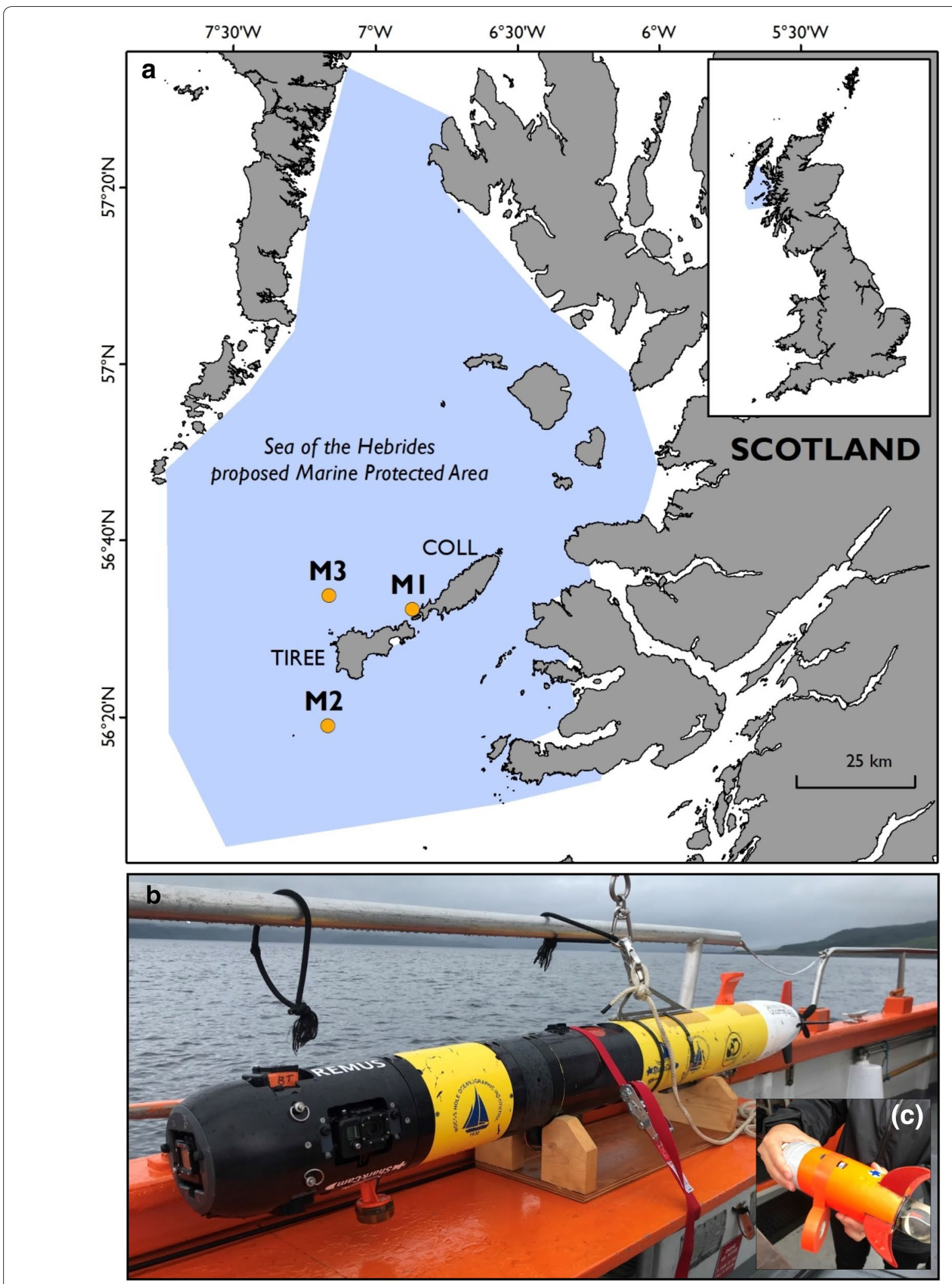

Fig. 1 Study location and REMUS-100 SharkCam. a Sea of the Hebrides proposed Marine Protected Area (pMPA; blue polygon) and deployment locations of REMUS-100 SharkCam on three missions (M1, M2 and M3). Great Britain and location of pMPA (inset), b REMUS-100 SharkCam prepared for deployment aboard tracking support vessel, c SharkCam acoustic retag to be fitted to shark 
Table 1 Tracking parameters for three missions by the REMUS-100 SharkCam on basking sharks in Scotland

\begin{tabular}{|c|c|c|c|}
\hline & Mission 1 & Mission 2 & Mission 3 \\
\hline Date & 11-Jul-19 & 14-Jul-19 & 16-Jul-19 \\
\hline Shark sex & Female & Female & Male \\
\hline Shark total length & $7-8 \mathrm{~m}$ & $6-7 m$ & $4-5 m$ \\
\hline Mission start & $12: 32$ & 09:56 & $13: 47$ \\
\hline Mission end & $16: 42$ & 12:05 & 18:23 \\
\hline Mission duration & $250 \mathrm{~min}$ & $129 \min$ & $276 \min$ \\
\hline AUV speed; mean ( \pm 1 S.D.) & $1.5 \mathrm{~m} \mathrm{~s}^{-1}(0.5)$ & $0.9 \mathrm{~m} \mathrm{~s}^{-1}(0.6)$ & $1.5 \mathrm{~m} \mathrm{~s}^{-1}(0.4)$ \\
\hline Shark depth; mean ( \pm 1 S.D.) & $15.6 \mathrm{~m}(6.5)$ & 15.3 m (12.8) & $31.8 \mathrm{~m}(21.9)$ \\
\hline Shark depth (maximum) & $25.0 \mathrm{~m}$ & $59.7 \mathrm{~m}$ & $63.7 \mathrm{~m}$ \\
\hline Water temperature; mean ( \pm 1 S.D.; range) & $11.3^{\circ} \mathrm{C}(0.2 ; 11.1-12.0)$ & $11.1^{\circ} \mathrm{C}(0.7 ; 10.3-13.1)$ & $11.2^{\circ} \mathrm{C}(1.0 ; 9.2-12.3)$ \\
\hline Chl-a concentration; median (IQR) & $1.2 \mathrm{mg} \mathrm{m}^{3}(1.06-1.43)$ & $0.7 \mathrm{mg} \mathrm{m}^{3}(0.46-0.83)$ & $0.8 \mathrm{mg} \mathrm{m}^{3}(0.59-1.17)$ \\
\hline \multicolumn{4}{|l|}{ AUV-retag tracking offsets } \\
\hline Forward-aft & $3 \mathrm{~m}$ aft & $1 \mathrm{~m}$ aft & $1 \mathrm{~m}$ aft \\
\hline Port-starboard & $0 \mathrm{~m}$ & $2 \mathrm{~m}$ port & $2.5 \mathrm{~m}$ port \\
\hline Above-below & $1 \mathrm{~m}$ below & $1 \mathrm{~m}$ above & $1.5 \mathrm{~m}$ above \\
\hline Minimum AUV altitude & $6 \mathrm{~m}$ & $2 \mathrm{~m}$ & $3 \mathrm{~m}$ \\
\hline Minimum AUV depth & $1 \mathrm{~m}$ & $1 \mathrm{~m}$ & $3 \mathrm{~m}$ \\
\hline Maximum permitted AUV depth & $80 \mathrm{~m}$ & $90 \mathrm{~m}$ & $90 \mathrm{~m}$ \\
\hline $\begin{array}{l}\text { Cumulative duration shark observed (\% of mission } \\
\text { duration) }\end{array}$ & $36 \min (14 \%)$ & $20 \min (16 \%)$ & $90 \min (33 \%)$ \\
\hline Number of contacts events with shark & 2 & 6 & 3 \\
\hline Horizontal visibility (\% tracking duration) & Mission 1 (\%) & Mission 2 (\%) & Mission 3 (\%) \\
\hline$\leq 5 \mathrm{~m}$ & 12 & - & - \\
\hline 5 to 7 & 23 & - & - \\
\hline 7 to 10 & 65 & 19 & 48 \\
\hline 10 to 15 & - & 81 & 29 \\
\hline 15 to 20 & - & - & 23 \\
\hline
\end{tabular}

Times given in UTC (Coordinated Universal Time). Tracking offsets are relative to the retag attached to the shark. Visibility was estimated from the video data, using the seabed, or other features visible to estimate visibility in five binned intervals

of the AUV was problematic, which caused the AUV to contact the seabed. Consequently, the mission was terminated after 129 min. During the mission the tracking vessel followed the AUV and shark for $7.6 \mathrm{~km}$, with the shark making one large looping movement (Fig. 3c). When the AUV cameras could record the shark, the shark was recorded swimming $1.7 \mathrm{~m}$ (median value, IQR $\pm 0.5 \mathrm{~m}$ ) above the seabed, and the video data revealed that this was predominantly rocky benthos with few defining features (Fig. 2e). Kelp coverage varied from sparse to dense, and benthic species observed include sea stars, urchins, sea cucumbers sponges and multiple unidentified fish species. The shark also spent time at the sea surface and swimming mid-water (Fig. 4b). Surface feeding was filmed by the AUV for a cumulative 1 min $28 \mathrm{~s}$, no other feeding was observed. During this feeding event the retag data revealed that the shark spent a total of $25 \mathrm{~min}$ at the surface $(<2 \mathrm{~m}$ depth). AUV cameras allowed the absence of claspers (male copulatory organs) to be confirmed (i.e. the shark was female) and some minor scarring was evident on the left pectoral fin and caudal fin. Distinctive scarring on the nose of the shark was evident. No courting or mating behaviours were observed. The AUV passed through a cloud of faeces from this shark. It was possible to make several estimates of TBF from the video data; TBF did not vary between the seabed $(0.19 \pm 0.02 \mathrm{~Hz}, n=8)$ or midwater $(0.22 \pm 0.06 \mathrm{~Hz}, n=5$; Wilcox test; $W=22$, $P=0.83)$. The AUV was configured to track closer to the retag $(1 \mathrm{~m}$ aft $)$ to address the poor visibility in Mission 1 , but further to the side of the shark and above it to reduce the chance of contact. While the shark was on the surface the tracking offset above the animal could not be used, and the AUV made contact with the shark on six occasions (three with the caudal fin, two with the pelvic fins and one to the flank). This resulted in the shark accelerating away from the AUV 

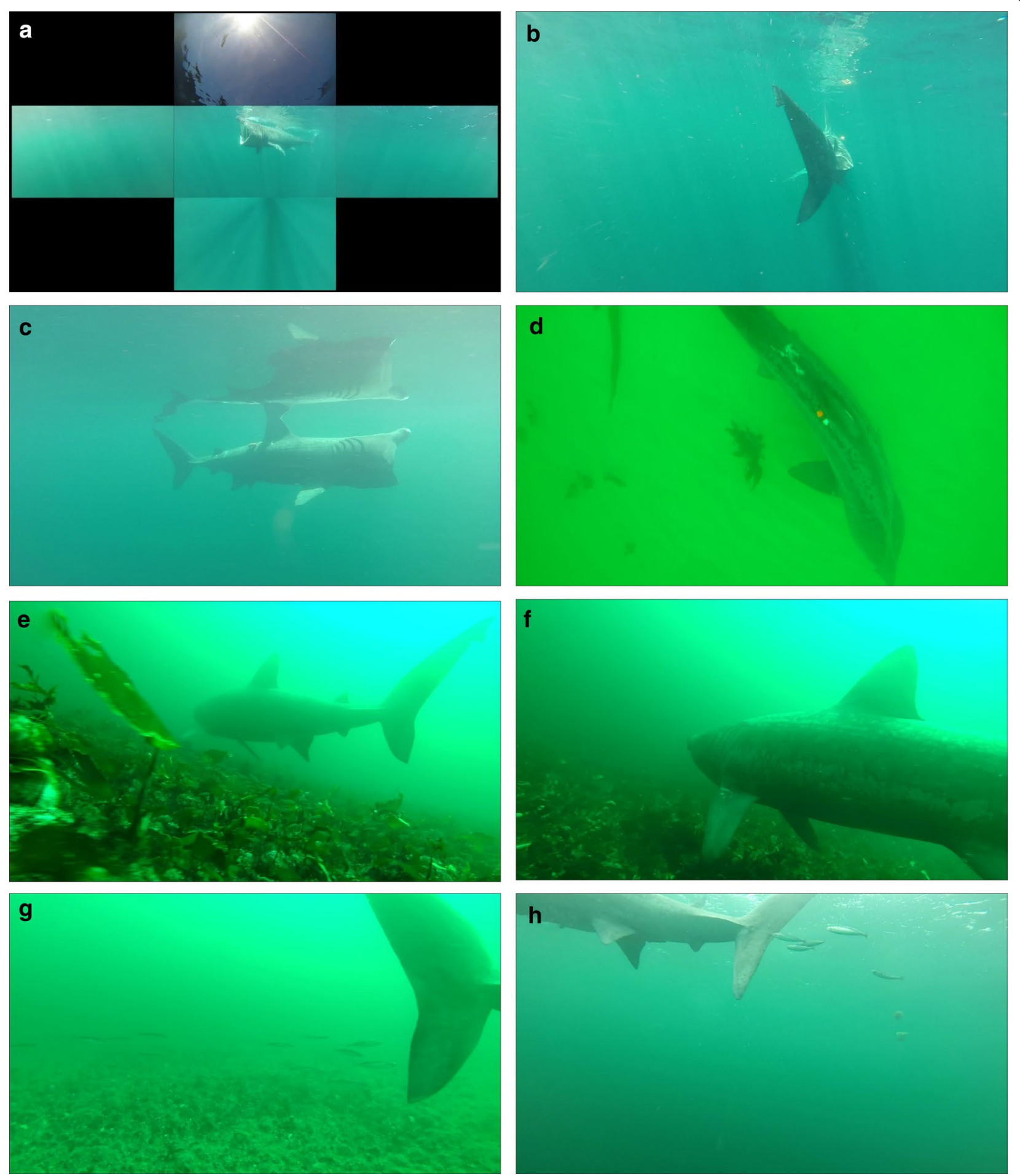

Fig. 2 Views of basking sharks from REMUS-100 SharkCam. a Basking shark feeding at the surface assembled into a multi-camera display, b basking shark swimming beneath the surface (retag visible to the right of the sharks dorsal fin), $\mathbf{c}$ basking shark feeding at surface, $\mathbf{d}$ basking shark swimming over sandy seafloor (retag visible to the right of the sharks dorsal fin) and $\mathbf{e}, \mathbf{f}$ basking shark swimming over kelp, and $\mathbf{g}, \mathbf{h}$ schools of horse mackerel following the caudal fin of basking sharks 


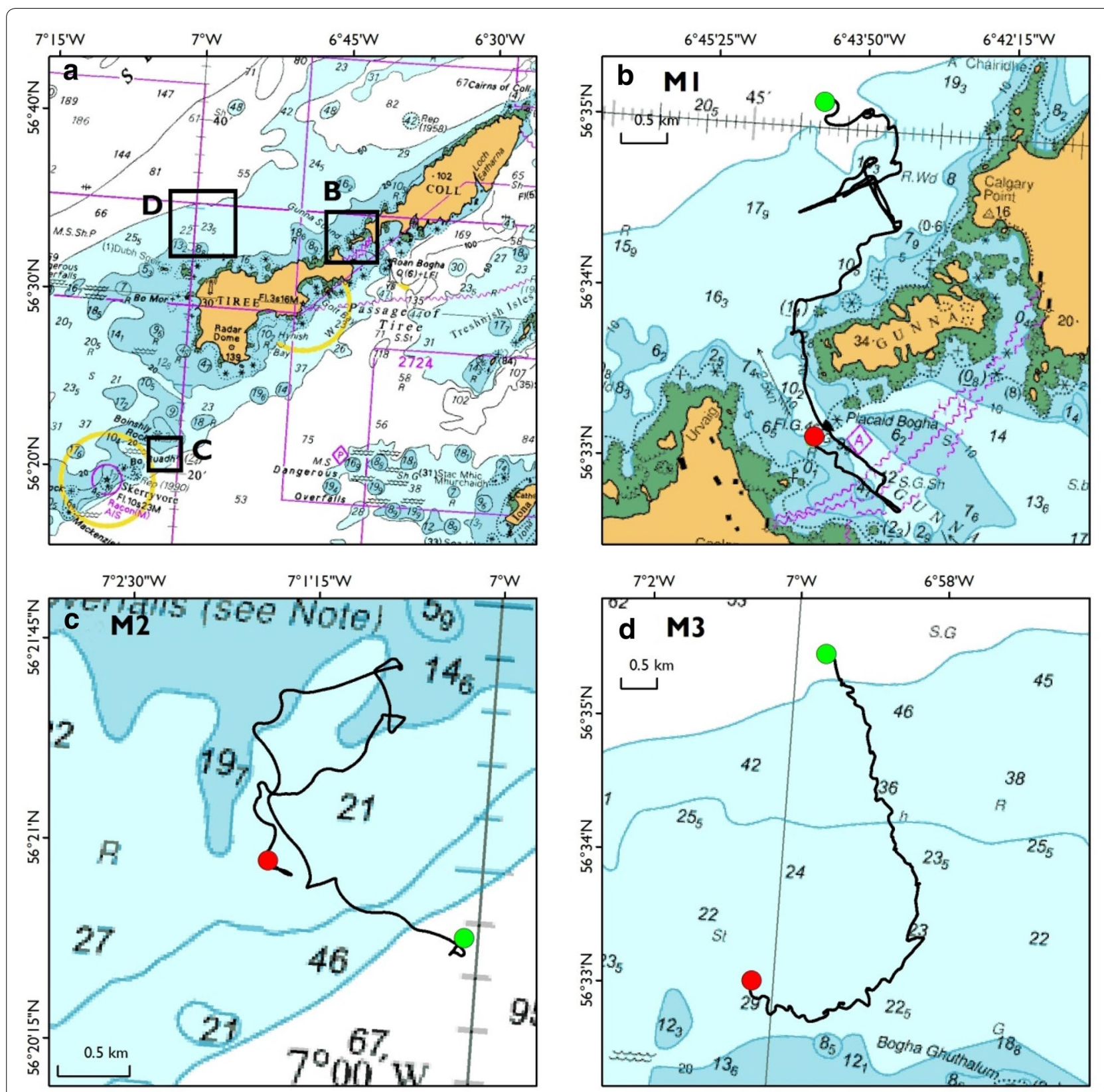

Fig. 3 Movement trajectories of support vessel following tagged basking sharks during REMUS-100 SharkCam missions. a Coll and Tiree, b Mission 1 (M1) 11-Jul-2019, c Mission 2 (M2) 14-Jul-2019, and d Mission 3 (M3) 16-Jul-2019

out of view. Horse mackerel (>20; Trachurus trachurus) followed the shark at the base of its tail fin as it was swimming near to the seabed (Fig. $2 \mathrm{~g}$ ). The horse mackerel could be seen contacting the shark caudal fin on multiple occasions, suggesting they may be using the shark as a cleaning surface. Horse mackerel also interacted with the aft of the AUV for approximately $30 \mathrm{~s}$ until the AUV increased speed to follow the retag.

\section{Mission 3}

The shark was tagged approximately $7.5 \mathrm{~km}$ northwest of Tiree and throughout tracking (276 min) swam south west and then west when nearing Tiree, forming a large 


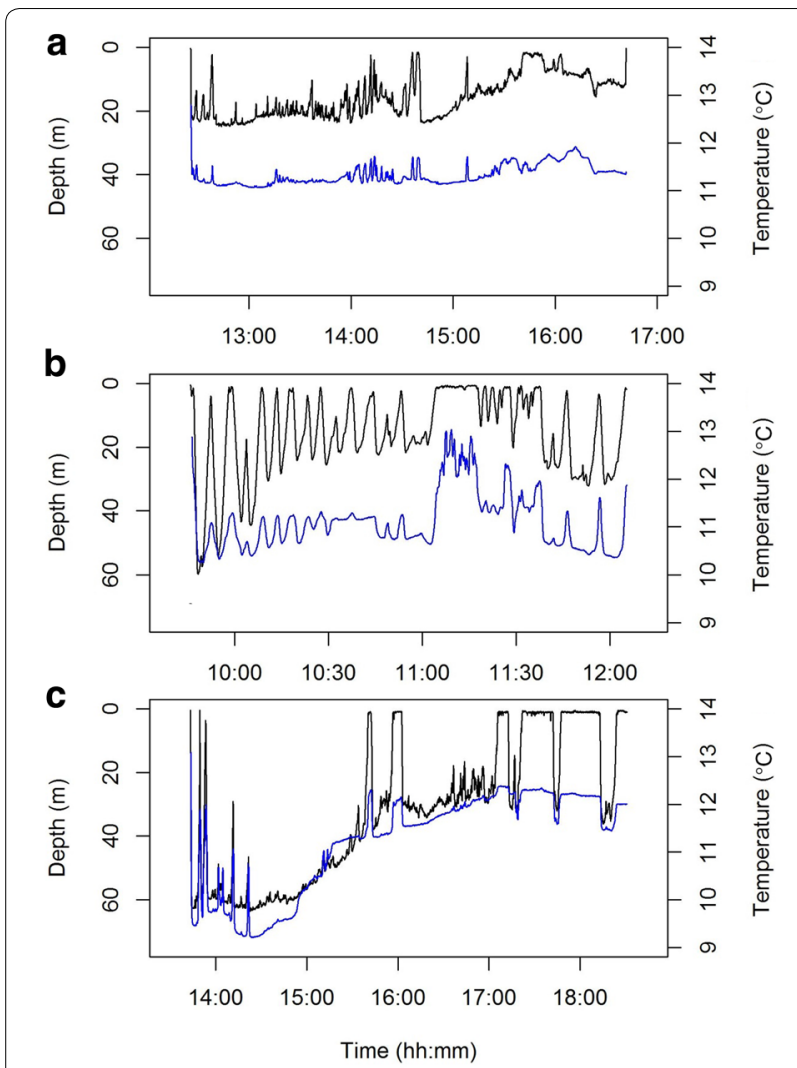

Fig. 4 Depth and temperature profiles from three sharks. Time series of depth (black line) and water temperature (blue line) from three basking (a-c for Missions 1 to 3, respectively) from the retag

arc (Fig. 3d). Courting or mating behaviours were not observed. During the first two hours of the tracking, the horizontal visibility of the sea water was 7 to $15 \mathrm{~m}$ (Table 1). When visible in the video data the shark travelled $1.1 \mathrm{~m}$ (median, IQR $1.7 \mathrm{~m}$ ) above the sandy and gravelly seabed. The shark then moved towards more shallow waters heading towards Tiree and travelled over rocky substrate covered by urchins and sponges but did not encounter any macroalgae. Although horizontal visibility was poor in coastal water, claspers could be discriminated from the upward and starboard facing cameras as the shark swam over the AUV, as well as a lamprey between the pelvic fins. There was also possible scarring from a lamprey at the base of the right side of the dorsal fin. The tracking vessel travelled $10.3 \mathrm{~km}$ while tracking the shark and AUV. The shark predominantly spent time within a few metres of the sea floor, but ascended towards shallower water on 16 occasions, undertaking characteristic yo-yo dives (Fig. 4c). At the surface, the shark was normally filmed swimming with its mouth closed, except for a single mouth opening event lasting $4 \mathrm{~s}$ and there was no other feeding evident throughout the video. Acoustic tracking of the AUV and the retag revealed the AUV made 131 circling events around the shark throughout the tracking period, while the shark (retag) made 114 circling events. Tail-beat frequency was measured when the tail of the shark was captured in the video data $0.29 \pm 0.06 \mathrm{~Hz}$ (mean $\pm 1 \mathrm{SD}$, range 0.18 to $0.58 \mathrm{~Hz}, n=34$ ). The AUV was configured to track $0.5 \mathrm{~m}$ further to the side and above the shark than Mission 2, which reduced contact events to three occasions, once on the tail recorded by the port-facing camera, once against the caudal peduncle and against the dorsal fin, both of which were recorded by the bow camera.

\section{Discussion}

This study contributes to an expanding base of literature on biologging, in which revolutions in camera technology and miniaturization of tags are providing insights into behaviours [25-27] as well as social context [28, 29] and predator/prey fields [30-33]. The present study is the first successful autonomous tracking of a basking shark, adding to more than a dozen expeditions utilizing the REMUS-100 SharkCam AUV to track and simultaneously film marine vertebrates of interest (see also [22, 24]). The combination of the REMUS-100 and retag provides rich insights, because the AUV can autonomously follow and film the shark while also collecting environmental data, while the retag can provide information about the movement and behaviour of the shark itself. Our work revealed sharks spent time near the seabed, a behaviour not routinely reported for the species. This is an important insight and could directly influence assessments of putative threats for the species and subsequent management strategies. An important consideration for all animal biologging studies is 'observer bias' (i.e. the effect that burdening animals with tags may have on their subsequent behaviour [34-36]) and that tagging sharks with retags and following them with an autonomous vehicle may have important methodological and ethical considerations as well. In the present study, the AUV made contact with the sharks, and the sharks accelerated away from the AUV with approximately twice their normal tail-beat frequency (but it was not possible to record the duration of this escape response until normal swimming resumed). Tail-beat frequencies observed during AUV tracking (when animals were not disturbed by contact events) were within the range observed for routine swimming by these sharks $(0.49 \mathrm{~Hz} \pm 0.12)$, which has been measured using animal-borne accelerometry tags (Rudd et al. In Review). Greenland sharks swim with approximately half the tail-beat frequency $(0.15 \mathrm{~Hz}$, [37], but in water of $2.3{ }^{\circ} \mathrm{C}$, compared to $11{ }^{\circ} \mathrm{C}$ in the present study. Behavioural modification due to contact events, or heightened alertness due to the presence of the AUV, are 
likely to have had energetic consequences and could have prevented conspecific sharks from approaching, and this should be considered in any future work. Indeed, the circling behaviour of the basking sharks tracked in the present study may have been a result of the AUV disturbing the sharks. Previously published work on basking sharks has had a spatio-temporal resolution of tens of metres to $\mathrm{kms}$, and hours $[13,14]$, and thus it is not possible to compare the circling behaviour with known fine-scale movement patterns of sharks in this putative breeding ground [17]. White sharks followed by the REMUS travelled primarily in a straight line at a constant speed [21, $23,24]$ and leatherback turtles surfaced between shorter, more variable dives [22]. The present study highlights that the utility of AUV studies should be individually determined based on the behaviour of the target species and that multiple iterations may be needed to minimize the effect of the vehicle presence on the animal's behaviour. In addition to elucidating tail-beat frequency, which can feed into energetic modelling [38], the AUV also allowed the first fine-scale (centimetre) monitoring of basking sharks biotic and abiotic environment, and that basking sharks spend considerable time associated with the seabed, a behaviour perhaps not often considered for a pelagic feeding species.

The locations in which basking sharks breed remains enigmatic, although the notable courtship-like behaviour exhibited by basking sharks in Scottish waters [16] strongly suggest that breeding may occur there. It is of note that sharks filmed in the present study spent much of the time that they were in view not feeding (i.e. with their mouths closed). Although this could be due to observer effect (i.e. disturbance from the AUV from its physical presence, electromagnetic fields or from detection of particle motion created by the AUV pressure wave), it is also suggestive that basking sharks may not visit Scottish waters solely to feed. In order to more objectively test this, future work could employ directly attached cameras to capture footage, both over a greater duration and over a greater portion of the diel cycle. In addition, surveying technologies such as multi-beam sonar or side-scan sonar, may be useful to elucidate the spatio-temporal occurrence of basking sharks away from the surface where they cannot be visually detected.

\section{Conclusions}

This study is the first to successfully use an AUV to gain insight into the sub-surface behaviour of basking sharks. Our work did not reveal breeding or courtship behaviours, however the AUV and retag combination revealed a greater than might be expected association with the seabed, particularly given the typical perception of the species as a pelagic or near-surface filter feeding shark.
The AUV further provided a rich near-stereoscopic overview of fish movement with environmental context inaccessible by other technologies. The method could have broad application across a range of other large marine vertebrate taxa, although we highlight that careful attention is needed to refine and optimize tracking offsets to minimize disturbance to the target animal, while still collecting useful video data.

\section{Methods}

Basking sharks were sighted feeding in surface waters of the Inner Hebrides, Scotland, and were tagged using a transponder beacon, also recording temperature and depth (1 $\mathrm{m}$ accuracy), known as 'retag' (Fig. 1c). The retag (approx. $4.4 \%$ of the sharks frontal area) was tethered to an intra-muscular dart attached to the shark's dorsal musculature. The REMUS-100 (AUV) can locate and autonomously follow the retag and hence the shark using an onboard $360^{\circ}$ hydrophone array and tracking system (1-s ping interval, $25 \mathrm{kHz}$ frequency and approx. $158 \mathrm{~dB}$ re $1 \mu \mathrm{Pa}$ source level). Elasmobranchs are thought to detect the particle motion component, rather than the pressure component, of sound, and are known to be sensitive to sounds up to $1.5 \mathrm{kHz}$ [39]. We therefore think it unlikely that basking sharks were disturbed by the retag or acoustic tracking system. Real-time data regarding AUV and retag state (e.g. power level, depth) could also be retrieved from these instruments using an acoustic modem aboard the support vessel. These data also allowed the relative positions of the instruments to be monitored as autonomous tracking was underway and permitted control of the AUV at the end of tracking to return it to the support vessel. As such, changes could be made, if necessary, to the behaviour of AUV without physically recovering the device. The retag on the shark was acoustically commanded to release from the shark at the end of each mission, and the buoyant retag floated to the surface where it could be retrieved by a support vessel using an acoustic transducer and a VHF radio receiver.

It is not possible to transmit a real-time video feed from the AUV-mounted cameras to support positioning of the AUV relative to the tagged shark. Therefore, the AUV was programmed with tracking offsets (AUV offset distance $(\mathrm{m})$ from the retag in the $X, Y$ and $Z$ dimensions), intended to automatically keep the AUV within filming range of the shark. Tracking offsets were refined after each mission and before the next as a result of watching the video data to optimize the filming position and to minimize the opportunity of contact with the animal. Additional offsets were used to prevent the AUV approaching the seabed (minimum altitude), or the surface (minimum depth), so to further minimize the potential for contact with the seabed, 
the tracked animal or other watercraft. When the AUV was greater than $20 \mathrm{~m}$ from the tag it moved at its maximum possible speed and altered heading and position in the water column to catch up to the retag and slowed as it approached. Minimum movement speed of the AUV was $70 \mathrm{~cm} \mathrm{~s}^{-1}$. As a precautionary measure, the AUV is positively buoyant in the event of electrical or mechanical failure. The AUV must therefore always be moving in the horizontal plane to prevent it from rising to the surface. As such, if the retag moves at $<70 \mathrm{~cm} \mathrm{~s}^{-1}$, the AUV circles to maintain horizontal travel relative to the pre-programmed tracking offsets. The altitude (vertical distance from seabed) of the shark could be determined when the AUV was in visual range of the shark by using information on depth of the retag, and depth and altitude of the AUV (accurate to $\pm 1 \%$ of depth reading).

Video data obtained from the AUV were assembled into a multi-camera display in Adobe Premiere Pro, and viewed at double speed, noting every time the shark came into view and on which camera they were observed. Depth and temperature data from the AUV, habitat type data, and retag and tracking vessel data were analysed using R (R Core Team, 2019) \& ArcGIS (ESRI).

\section{Acknowledgements}

The REMUS-100 SharkCam technology is owned and operated by the Woods Hole Oceanographic Institution (WHOI). The authors wish to thank the following boat operators, skippers and crew: Richard Darby, Chris Jackson, lain Malcolm, James Fairbairns, Harry Mansfield and Rona McCann.

\section{Authors' contributions}

Conducted the fieldwork, reviewed drafts of the manuscript: $\mathrm{LAH}, \mathrm{OE}, \mathrm{SMH}$, KC, AK, JR, SW, NY, MJW. Reviewed video footage: OE, CK, JR. All authors read and approved the final manuscript.

\section{Funding}

The project was funded by WWF/Sky Ocean Rescue, Scottish Natural Heritage $(\mathrm{SNH}), \mathrm{WHOl}$ and the University of Exeter, with additional support from Sea World Busch Gardens Conservation Fund and Hydroid Inc.

\section{Ethics approval and consent to participate}

All work was carried out in accordance with the UK HM Government Home Office under the Animals (Scientific Procedures) Act 1986 (Licence P23C6EFD2) and under the Wildlife \& Countryside Act 1981 (as amended) (Licence: 124812) and reviewed by the University of Exeter's Animal Welfare and Ethical Review board (AWERB).

\section{Consent for publication}

Not applicable.

\section{Competing interests}

The authors declare no competing interests.

\section{Author details}

${ }^{1}$ Environmental Biology Group, Hatherly Laboratories, University of Exeter, Prince of Wales Road, Exeter EX4 4PS, UK. ${ }^{2}$ College of Life and Environmental Sciences, University of Exeter, Penryn Campus, Penryn TR10 9FE, Cornwall, UK. ${ }^{3}$ NatureScot, Great Glen House, Leachkin Road, Inverness IV3 8NW, UK. ${ }^{4}$ Oceanographic Systems Laboratory, Woods Hole Oceanographic Institution, 86 Water St., Woods Hole, MA 02543, USA.
Received: 7 April 2020 Accepted: 4 August 2020

Published online: 17 August 2020

\section{References}

1. Hussey NE, Kessel ST, Aarestrup K, Cooke SJ, Cowley PD, Fisk AT, Harcourt RG, Holland KN, Iverson SJ, Kocik JF, Mills Fleming JE, Whoriskey FG. Aquatic animal telemetry: a panoramic window into the underwater world. Science. 2015;348:1255642.

2. Kays R, Crofoot MC, Jetz W, Wikelski M. Terrestrial animal tracking as an eye on life and planet. Science. 2015. https://doi.org/10.1126/scien ce.aaa2478.

3. Bishop CM, Spivey RJ, Hawkes LA, Batbayar N, Chua B, Frappell PB, Milsom WK, Natsagdorj T, Newman SH, Scott GR, Takekawa JY, Wikelski M, Butler PJ. The roller coaster flight strategy of bar-headed geese conserves energy during Himalayan migrations. Science. 2015;347:250-4.

4. Botha A, Lease HM, Fuller A, Mitchell D, Hetem RS. Biologging subcutaneous temperatures to detect orientation to solar radiation remotely in savanna antelope. J Exp Zool Part A Ecol Integr Physiol. 2019;331:267-79.

5. Meir JU, Champagne CD, Costa DP, Williams CL, Ponganis PJ. Extreme hypoxemic tolerance and blood oxygen depletion in diving elephant seals. Am J Physiol Regul Integr Comp Physiol. 2009;297:R927-39.

6. Wilmers CC, Nickel B, Bryce CM, Smith JA, Wheat RE, Yovovich V. The golden age of bio-logging: how animal-borne sensors are advancing the frontiers of ecology. Ecology. 2015;96:1741-53.

7. Mcintyre T. Trends in tagging of marine mammals: a review of marine mammal biologging studies. Afr J Mar Sci. 2014;36:409-22.

8. Godley BJ, Blumenthal JM, Broderick AC, Coyne MS, Godfrey MH, Hawkes $L A$, Witt MJ. Satellite tracking of sea turtles: where have we been and where do we go next? Endang Species Res. 2008:4:3-22.

9. Hays GC, Hawkes LA. Satellite tracking sea turtles: opportunities and challenges to address key questions. Front Mar Sci. 2018;5:432.

10. Queiroz N, Humphries NE, Mucientes G, Hammerschlag N, Lima FP, Scales KL, Miller PI, Sousa LL, Seabra R, Sims DW. Ocean-wide tracking of pelagic sharks reveals extent of overlap with longline fishing hotspots. PNAS. 2016;113(6):1582-7.

11. Priede IG. A basking shark (Cetorhinus maximus) tracked by satellite together with simultaneous remote sensing. Fish Res. 1984;2:201-16.

12. Austin RA, Hawkes LA, Doherty PD, Henderson $S M$, Inger $R$, Johnson $L$, Pikesley SK, Solandt JL, Speedie C, Witt MJ. Predicting habitat suitability for basking sharks (Cetorhinus maximus) in UK waters using ensemble ecological niche modelling. J Sea Res. 2019;153:101767.

13. Doherty PD, Baxter JM, Gell FR, Godley BJ, Graham RT, Hall G, Hall J, Hawkes LA, Henderson SM, Johnson L, Speedie C, Witt MJ. Long-term satellite tracking reveals variable seasonal migration strategies of basking sharks in the north-east Atlantic. Sci Rep. 2017;7:42837.

14. Doherty PD, Baxter JM, Godley BJ, Graham RT, Hall G, Hall J, Hawkes LA, Henderson SM, Johnson L, Speedie C, Witt MJ. Testing the boundaries: seasonal residency and inter-annual site fidelity of basking sharks in a proposed marine protected area. Biol Conserv. 2017;209:68-75.

15. Witt MJ, Hardy T, Johnson L, Mcclellan CM, Pikesley SK, Ranger S, Richardson PB, Solandt JL, Speedie C, Williams R, Godley BJ. Basking sharks in the northeast Atlantic: spatio-temporal trends from sightings in UK waters. Mar Ecol Prog Ser. 2012;459:121-34.

16. Gore M, Abels L, Wasik S, Saddler L, Ormond R. Are close-following and breaching behaviours by basking sharks at aggregation sites related to courtship? J Mar Biol Assoc U K. 2019;99:681-93.

17. Speedie CD, Johnson LA, Witt MJ. Basking shark hotspots on theWest Coast of Scotland: key sites, threats and implications for conservation. Scottish Natural Heritage Commissioned Report No.339. 2009.

18. Pratt HL, Carrier JC. A review of elasmobranch reproductive behavior with a case study on the nurse shark, Ginglymostoma cirratum. Environ Biol Fishes. 2001;60:157-88.

19. Waller. Synchronised swimmers. UK: BBC Wildlife; 2000.

20. Bicknell AWJ, Godley BJ, Sheehan EV, Votier SC, Witt MJ. Camera technology for monitoring marine biodiversity and human impact. Front Ecol Environ. 2016;14:424-32.

21. Kukulya AL, Stokey R, Jaffre F, Hoyos-Padilla ME, Skomal GB. 3D real-time tracking, following and imaging of white sharks with an autonomous 
underwater vehicle. In: Proceedings of Oceans '15, 2015 Geneva. p. 18-21.

22. Dodge KL, Kukulya AL, Burke E, Baumgartner MF. TurtleCam: a "Smart" autonomous underwater vehicle for investigating behaviors and habitats of sea turtles. Front Mar Sci. 2018:5:90.

23. Kukulya AL, Stokey R, Fiester C, Hoyos-Padilla EM, Skomal G. Multi-vehicle autonomous tracking and filming of white sharks Carcharodon carcharias. Autonomous Underwater Vehicles (AUV), IEEE/OES (Tokyo). p. 423-30. 2016.

24. Skomal GB, Hoyos-Padilla EM, Kukulya A, Stokey R. Subsurface observations of white shark Carcharodon carcharias predatory behaviour using an autonomous underwater vehicle. J Fish Biol. 2015;87:1293-312.

25. Jewell OJD, Gleiss AC, Jorgensen SJ, Andrzejaczek S, Moxley JH, Beatty SJ, Wikelski M, Block BA, Chapple TK. Cryptic habitat use of white sharks in kelp forest revealed by animal-borne video. Biol Let. 2019;15:20190085.

26. Pearson HC, Jones PW, Srinivasan M, Lundquist D, Pearson CJ, Stockin KA, Machovsky-Capuska GE. Testing and deployment of C-VISS (cetaceanborne video camera and integrated sensor system) on wild dolphins. Mar Biol. 2017;164:42.

27. Wilson K, Littnan C, Halpin PN, Read AJ. Integrating multiple technologies to understand the foraging behaviour of Hawaiian monk seals. Royal Society Open Science. 2017:4:160703.

28. Takahashi A, Sato K, Naito Y, Dunn MJ, Trathan PN, Croxall JP. Penguinmounted cameras glimpse underwater group behaviour. Proc R Soc Lond B. 2004;271:S281-2.

29. Yoda K, Murakoshi M, Tsutsui K, Kohno H. Social interactions of juvenile brown boobies at sea as observed with animal-borne video cameras. PLOS ONE. 2011;6:e19602.

30. Handley JM, Thiebault A, Stanworth A, Schutt D, Pistorius P. Behaviourally mediated predation avoidance in penguin prey: in situ evidence from animal-borne camera loggers. R Soc Open Sci. 2018;5:171449.

31. Heaslip SG, Iverson SJ, Bowen WD, James MC. Jellyfish support high energy intake of leatherback sea turtles (Dermochelys coriacea): video evidence from animal-borne cameras. PLoS ONE. 2012;7:e33259.
32. Tremblay Y, Thiebault A, Mullers R, Pistorius P. Bird-borne video-cameras show that seabird movement patterns relate to previously unrevealed proximate environment, not prey. PLoS ONE. 2014;9:e88424.

33. Votier SC, Bicknell A, Cox SL, Scales KL, Patrick SC. A bird's eye view of discard reforms: bird-borne cameras reveal seabird/fishery interactions. PLOS ONE. 2013;8:e57376.

34. Vandenabeele SP, Shepard EL, Grogan A, Wilson RP. When three per cent may not be three per cent; device-equipped seabirds experience variable flight constraints. Mar Biol. 2012;159:1-14.

35. Wilson RP, Holton M, Wilson VL, Gunner R, Tysse B, Wilson Gl, Quintana F, Duarte C, Scantlebury DM. Towards informed metrics for examining the role of human-induced animal responses in tag studies on wild animals. Integr Zool. 2019;14(1):17-29.

36. McMahon CR, Hindell MA, Harcourt RG. Publish or perish: why it's important to publicise how, and if, research activities affect animals. Wildlife Res. 2012:39:375-7.

37. Watanabe YY, Lydersen C, Fisk AT, Kovacs KM. The slowest fish: swim speed and tail-beat frequency of Greenland sharks. J Exp Mar Biol Ecol. 2012:426:5-11.

38. Gough WT, Segre PS, Bierlich KC, Cade DE, Potvin J, Fish FE, Dale J, di Clemente J, Friedlaender AS, Johnston DW, Kahane-Rapport SR, Kennedy J, Long JH, Oudejans M, Penry G, Savoca MS, Simon M, Videsen SKA, Visser F, Wiley DN, Goldbogen JA. Scaling of swimming performance in baleen whales. J Exp Biol. 2019;222:204172.

39. Chapuis L, Collin SP, Yopak KE, Mccauley RD, Kempster RM, Ryan LA, Schmidt C, Kerr CC, Gennari E, Egeberg CA, Hart NS. The effect of underwater sounds on shark behaviour. Sci Rep. 2019;9:6924. https://doi. org/10.1038/s41598-019-43078-w.

\section{Publisher's Note}

Springer Nature remains neutral with regard to jurisdictional claims in published maps and institutional affiliations.
Ready to submit your research? Choose BMC and benefit from:

- fast, convenient online submission

- thorough peer review by experienced researchers in your field

- rapid publication on acceptance

- support for research data, including large and complex data types

- gold Open Access which fosters wider collaboration and increased citations

- maximum visibility for your research: over $100 \mathrm{M}$ website views per year

At BMC, research is always in progress.

Learn more biomedcentral.com/submissions 